Impression management and retospective sense-making in corporate narratives: a social psychology perspective.

Merkl-Davies, D.M.; Brennan, N.; McLeay, S.

\title{
Accounting, Auditing and Accountability Journal
}

DOI:

$10.1108 / 09513571111124036$

Published: 01/01/2011

Peer reviewed version

Cyswllt i'r cyhoeddiad / Link to publication

Dyfyniad o'r fersiwn a gyhoeddwyd / Citation for published version (APA):

Merkl-Davies, D. M., Brennan, N., \& McLeay, S. (2011). Impression management and retospective sense-making in corporate narratives: a social psychology perspective. Accounting, Auditing and Accountability Journal, 24(3), 315-344.

https://doi.org/10.1108/09513571111124036

\section{Hawliau Cyffredinol / General rights}

Copyright and moral rights for the publications made accessible in the public portal are retained by the authors and/or other copyright owners and it is a condition of accessing publications that users recognise and abide by the legal requirements associated with these rights. study or research.

download and print one copy of any publication from the public portal for the purpose of private

- You may not further distribute the material or use it for any profit-making activity or commercial gain

- You may freely distribute the URL identifying the publication in the public portal?

Take down policy

This article is (c) Emerald Group Publishing and permission has been granted for this version to appear here. Emerald does not grant permission for this article to be further copied/distributed or hosted elsewhere without the express permission from Emerald Group Publishing Limited.

Take down policy

If you believe that this document breaches copyright please contact us providing details, and we will remove access to the work immediately and investigate your claim. 
Impression management and retrospective sense-making in corporate narratives:

A social psychology perspective

\author{
Doris M. Merkl-Davies*, Niamh M. Brennan** \\ and Stuart J. McLeay \\ *Bangor University \\ **University College Dublin \\ *** University of Sussex
}

Address for correspondence:

Doris Merkl-Davies, Bangor Business School, Bangor University, Bangor, Gwynedd LL57 2DG, Great Britain. Tel.: 0044-(0)1248-382120; d.m.merkl-davies@ bangor.ac.uk.

\title{
Acknowledgements
}

This research is associated with the Accounting Harmonisation and Standardisation in Europe: Enforcement, Comparability and Capital Market Effects research project (Contract No. HPRN-CT-2000-00062) carried out by the HARMONIA network and funded by the European Commission Research Training Program. The authors acknowledge the helpful comments of Paul Dunmore from Massey University and two anonymous reviewers as a result of which the paper is much improved, and the guidance of the editors of $A A A J$. An earlier version of this paper was presented at the British Accounting Association Annual Conference at Heriot-Watt University in 2005. 


\title{
Impression management and retrospective sense-making in corporate narratives: A social psychology perspective
}

\begin{abstract}
Purpose - Prior accounting research views impression management predominantly though the lens of economics. Drawing on social psychology research we provide an alternative perspective on corporate annual narrative reporting as characterised by conditions of 'ex post accountability' (Aerts, 2005, p. 497). These give rise to either (i) impression management resulting from the managerial anticipation of the feedback effects of information and/or to (ii) managerial sense-making by means of the retrospective framing of organisational outcomes.

Design/methodology/approach - We use a content analysis approach pioneered by psychology research (Newman et al., 2003) which is based on the psychological dimension of word use to investigate the chairmen's statements of 93 UK listed companies.

Findings - Results suggest that firms do not use chairmen's statements to present an inaccurate view of organisational outcomes (self-presentational dissimulation). We find that negative organisational outcomes prompt managers to engage in retrospective sense-making, rather than to present a public image of organisational performance inconsistent with the view internally held by management (selfpresentational dissimulation). Further, managers of large firms use chairmen's statements to portray an accurate (i.e., consistent with organisational performance as reported in the financial statements), albeit favourable, image of the firm and of organisational outcomes (i.e., impression management by means of enhancement).

Research limitations - The content analysis approach adopted in the study analyses words out of context.

Practical implications - Corporate annual reporting may not only be understood from a behavioural perspective involving managers responding to objectively determined stimuli inherent in the accountability framework, but also from a symbolic interaction perspective which involves managers retrospectively making sense of organisational outcomes and events.

Originality/value - Our approach allows us to investigate three complementary scenarios of managerial corporate annual reporting behaviour: (i) self-presentational dissimulation (i.e., presenting an inaccurate view of organisational outcomes), (ii) impression management by means of enhancement (i.e., presenting an accurate, but favourable view of organisational outcomes), and (iii) retrospective sense-making.
\end{abstract}

Keywords: Impression management; Retrospective sense-making; Chairmen's statements; Social psychology.

Paper type: Research paper 


\section{INTRODUCTION}

Prior research focusing on impression management in a corporate reporting context is often either explicitly or implicitly based on economics-based theories, particularly agency theory (Merkl-Davies and Brennan, 2007). Managers are assumed to act rationally to maximise their utility by exploiting information asymmetries to mislead investors about financial performance and prospects. This manifests itself in reporting bias, i.e., the emphasis of positive organisational outcomes and the obfuscation of negative organisational outcomes in corporate narrative documents. What is more, managerial behaviour tends to be regarded as only minimally affected by social relations (Letza et al., 2008). However, we argue that managerial narrative disclosure decisions are affected by the social constraints arising from the (imagined) presence of the recipients of corporate reports who use the information in their decisionmaking.

Psychological factors thus may provide a richer explanation of managerial impression management than economic factors. For this reason, we adopt a social psychology perspective, which complements the narrow concept of economic rationality by viewing managerial behaviour as subject to social biases arising from the (imagined) presence of others whose behaviour management is trying to anticipate (Allport, 1954, p. 5). Accounting research can thus benefit from insights from social psychology which regards impression management as driven by social relations characterised by an anticipation of an evaluation of conduct (Frink and Ferris, 1998).

Users of corporate narrative documents have been shown to be susceptible to behavioural effects including a variety of cognitive and social biases. This prevent them from assessing reporting bias arising from the manipulation of the presentation and disclosure of information in corporate narrative documents (for example, Baird and Zelin 2000; Courtis 2004b; Elliott 2006; Frederickson and Miller 2004; Krische 2005).

However, the information communicated in corporate narrative documents impacts not only on the behaviour of the information recipients, but also on the behaviour of the information providers in the sense that they anticipate the potential undesirable consequences of information releases in the form of unfavourable analyst reports, 
credit ratings, or news reports (Prakash and Rappaport, 1977). If corporate narrative documents are regarded as a description of the decision behaviour of the firm's management and thus reflect managerial performance (Prakash and Rappaport, 1977, p. 35), then managers may be prompted to engage in impression management with the expectation that shareholders and stakeholders may respond in less undesirable ways. Alternatively, the process of anticipating the reactions of information recipients to managerial disclosures may prompt managers to engage in 'retrospective sensemaking' (Aerts, 2005, p. 496) which involves retrospectively framing organisational outcomes.

\subsection{Definition and scope}

This paper constitutes an empirical, interdisciplinary study of managerial impression management focusing on the less researched 'social' dimension of corporate narrative reporting. It is interdisciplinary in the sense that it draws on theoretical insights from social psychology and uses a content analysis approach developed by social psychology research to analyse impression management in 93 UK chairmen's statements of listed firms. We regard impression management as a social bias which involves "controlling or manipulating the attributions or impressions" (Tedeschi and Riess, 1981, p. 3) of others with the aim of being perceived favourably (Hooghiemstra, 2000, p. 60). Further, as the presence of shareholders/stakeholders impacts on the way managers think, feel and express themselves, corporate narrative documents contain psychological information which can be extracted by means of content analysis.

\subsection{Importance of studying narrative disclosures}

Driven by the realisation that fundamentals only explain a small fraction of share price movements (Cenesizoglu and Timmermann, 2008), accounting researchers have increasingly turned to the study of corporate narratives. They are either regarded as a means of providing incremental useful information to improve decision-making or, alternatively, as a means of providing biased information to mislead investors (MerklDavies and Brennan, 2007). If they are used opportunistically, this may result in capital misallocations and unfair wealth transfers from shareholders to managers (for example, in the form of increased compensation via share options). Impression management thus constitutes an important corporate governance and regulatory issue. 
The seriousness of this issue for both firms and shareholders is demonstrated by Rogers et al.'s (2009) finding that optimistic tone in earnings announcements is significantly associated with shareholder litigation. This suggests that corporate narrative documents may contain reporting bias and that investors are unable to assess this bias in the short term.

\subsection{Motivations, objectives and contribution of the paper}

In archival accounting research, psychology theories have been found to be useful to make predictions and interpret results (Koonce and Mercer, 2005). However, most prior research does not sufficiently use social psychology theories to provide insights into managerial impression management. This is particularly paradoxical, considering that this is the discipline in which impression management research originates. Our objective is to add richer explanations of impression management motivations and strategies using insights from psychology research. We also consider the possibility that the conditions of 'ex post accountability' (Aerts, 2005, p. 497) which characterise corporate annual reporting, may not only give rise to impression management, but also to the retrospective framing of organisational outcomes.

We introduce a method for uncovering impression management pioneered by psychology research (Newman et al. 2003). Unlike prior studies, which focus on the disclosure strategies used by management to present a favourable view of organisational performance, we focus on the linguistic indicators of the psychological processes involved in managers submitting to an inquiry by shareholders and stakeholders who evaluate organisational and managerial performance.

Our results from an empirical application of this method based on a sample of $93 \mathrm{UK}$ chairmen's statements of listed companies suggest that firms do not use corporate annual report documents to portray a public image of organisational performance inconsistent with the view internally held by management (self-presentational dissimulation). Rather, corporate narratives are used to portray an accurate (i.e., consistent with organisational performance as reported in the financial statements), albeit favourable, view of organisational outcomes and to retrospectively provide explanations of organisational outcomes and events. 
Section 2 discusses the theoretical assumptions underlying prior research. Section 3 introduces a social psychology perspective of corporate annual reporting. Section 4 outlines the research questions, hypotheses and the research method. Section 5 discusses the results and Section 6 concludes the paper.

\section{THEORETICAL BASIS OF PRIOR RESEARCH}

Prior research regards managers as rational, self-interested decision-makers and social interaction with firm outsiders by means of corporate reporting is regarded solely in terms of market exchange (Mouck, 1995). Impression management entails managers opportunistically taking advantage of information asymmetries. Managers use the discretion inherent in corporate narrative reporting by means of manipulating the presentation and disclosure of information in order to "distort readers' perceptions of corporate achievements" (Godfrey et al., 2003, p. 96). Similar to earnings management, impression management is viewed as constituting an inconsistency between the managerial view of organisational performance and the view conveyed publicly in corporate narrative documents (Healy and Wahlen, 1999, p. 368). Corporate narrative documents are considered to be potential impression management vehicles which can be used by managers to present a self-interested view of corporate performance (Bettman and Weitz, 1983; Staw et al., 1983; Abrahamson and Park, 1994; Beattie and Jones, 2000; Clatworthy and Jones, 2006; Mather et al., 2000). Impression management involves emphasising positive organisational outcomes (enhancement) or obfuscating negative organisational outcomes (concealment), for example, by including (more favourable) pro forma earnings numbers in corporate narratives or by displaying positive organisational outcomes more prominently than negative organisational outcomes (e.g., by means of positioning or highlighting). As negative organisational outcomes give rise to conflicts of interest between managers and shareholders, managers are assumed to be prompted to manipulate outsiders' perceptions of and decisions on financial performance and prospects, i.e., to engage in impression management (Aerts, 2005). Managerial motives may include benefitting from increased compensation, particularly via managerial stock options (Adelberg, 1979; Rutherford, 2003; Courtis, 2004a). 
Some impression management studies are either explicitly or implicitly based on a social psychology perspective. Impression management is viewed as a self-serving bias entailing the attribution of positive organisational outcomes to internal factors (taking responsibility for good performance) and of negative organisational outcomes to external circumstances (assigning blame for bad performance) (Aerts, 1994, 2001; Clatworthy and Jones, 2003). Self-serving bias is explained by reference to attribution theory (Heider, 1958; Jones and Davis, 1965; Kelley, 1967) which is concerned with people's explanations of events. Research suggests that, in an interactive context, people's attribution of actions and events is biased in the sense that they take credit for success and deny responsibility for failure (Knee and Zuckerman, 1996). Although prior research often acknowledges the social psychology roots of impression management in the form of performance attributions, the analysis tends to be carried out within an economics-based framework with managers acting as rational utility maximising individuals. We argue that self-serving bias may constitute a social bias resulting from the accountability context inherent in the corporate reporting process. What is more, prior research regards managerial corporate reporting behaviour as characterised by prospective rationality. This means that narrative disclosures are regarded as the result of purposeful, goal-directed behaviour, either aimed at providing useful incremental information or at providing misleading information (impression management). However, Aerts (2005) argues that corporate annual reporting may be characterised by retrospective rationality which involves making sense of actions and events that have already occurred.

\section{A SOCIAL PSYCHOLOGY PERSPECTIVE OF CORPORATE ANNUAL REPORTING}

The social psychology literature regards impression management as consisting of two different processes, namely impression motivation and impression construction (Leary and Kowalski, 1990). Impression motivation is concerned with the circumstances which motivate individuals to engage in impression management. Impression construction entails "choosing the kind of impression to create" and “deciding how [to] go about doing so" (Leary and Kowalski, 1990, pp. 35-36).

We first discuss the social factors impacting on impression motivation which we regard as embedded in, and dependent on, social relations. As impression 
management involves "the process by which people attempt to control the impressions others form of them" (Leary and Kowalski, 1990, p. 34), it is social in character. This means that the social 'presence' of others is an essential part of impression management. Thus, the determinants of impression management behaviour may be located externally in the social context, as well as internally within managers. As impression management in a corporate reporting context occurs in the (imagined) presence of outside parties, we regard it to be determined by the accountability relationship between management and financial and non-financial stakeholders. ${ }^{1}$

We then focus on impression construction which involves constructing public images that are either (i) a reflection of one's self-image or (ii) images which are inconsistent with one's self-concept (Leary and Kowalski, 1990, p. 40). The former entails managers using corporate annual documents to present an accurate (i.e., consistent with organisational performance as reported in the financial statements) but favourable view of organisational outcomes, whereas the latter entails "presenting images that are...not accurate" (Leary et al., 1994, p. 461). This is referred to as selfpresentational dissimulation (Leary and Kowalski, 1990, p. 40). In a corporate annual reporting context, it entails the managerial construction of public images of managerial actions and events that are inconsistent with the way management may view these actions and events. We introduce a new content analysis approach pioneered by psychology research which focuses on the linguistic indicators of the psychological processes underlying involved in self-presentational dissimulation.

\subsection{Accountability, impression motivation, and retrospective sense-making}

Schlenker et al. (1994, p. 634) defines accountability as "the condition of being answerable to audiences for performing up to certain standards, thereby fulfilling responsibilities, duties, expectations, and other charges". On the one hand, accountability entails the obligation of one party to provide explanations and justifications for its conduct to another party. On the other hand, it involves the first

\footnotetext{
${ }^{1}$ This implies a wide concept of accountability which views firms as reacting to the concerns of all external parties (Stanton and Stanton, 2002).
} 
party's behaviour being subject to the scrutiny, judgment and sanctioning of the second party.

According to Schlenker (1997), accountability involves three components which affect judgement and decision-making in different ways, namely (1) the inquiry component, (2) the accounting component, and (3) the verdict component. The inquiry component entails anticipating or submitting to an inquiry by an audience who evaluates one's actions and decisions in relation to specific prescriptions. The accounting component involves presenting one's version of events. This gives the individual the opportunity to describe, document, interpret, and explain relevant information with the purpose of constructing a personal account of events and providing reasons for their occurrence. The verdict component entails the audience delivering a verdict. This comprises both a judgment of the individual and the application of either social and material rewards or sanctions. Thus, the experience or anticipation of an evaluative appraisal is crucial to the concept of accountability.

Frink and Ferris (1998), who apply the concept of accountability in organisational research, establish the link between accountability and impression management. They argue that, in an accountability context, individuals engage in impression management in anticipation of an evaluation of their conduct. Impression management thus constitutes a way of influencing the impressions and decisions of relevant parties in order to win rewards and avoid sanctions. Thus, conditions of accountability foster impression management.

Managerial behaviour in the corporate reporting process can also be analysed in the context of an accountability framework. Managers are accountable to outside parties for their decisions and actions, with the annual report serving as an accountability mechanism to react to the concerns of external parties (Stanton and Stanton, 2002, p. 492). Thus, impression management can be conceptualised as arising from the inquiry component of corporate reporting with managers engaging in impression management in anticipation of an evaluation of their actions and decisions (primarily) by shareholders. Managers are assumed to engage in impression management to 
counteract undesirable consequences of information releases. ${ }^{2}$ Figure 1 illustrates the role of corporate narrative reporting in the accountability process.

Figure 1: Role of corporate narrative reporting in the accountability process

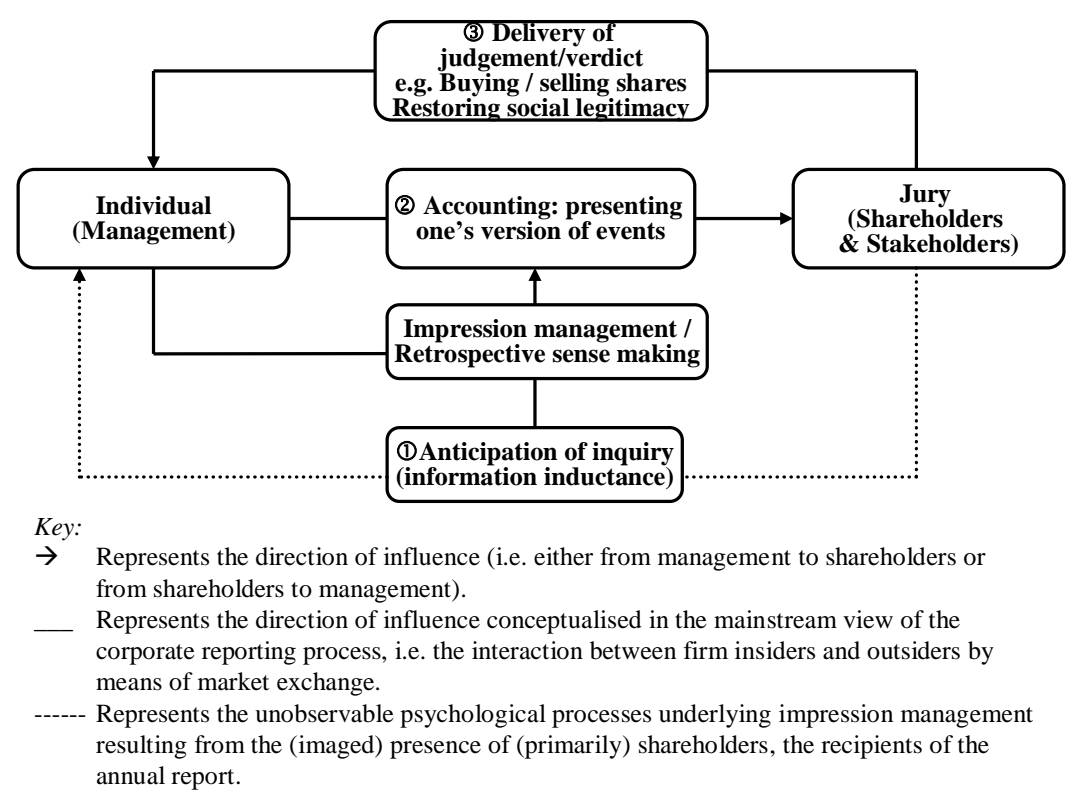

The process of anticipating the reactions of information recipients to managerial disclosures is referred to as 'information inductance' (Prakash and Rappaport 1977). Impression management can thus be regarded as resulting from the behavioural impact of information on managers who aim to control the feedback effects of reported information by means of altering it before it is released. Alternatively, Aerts (2005) argues that the accountability context of corporate annual reporting prompts managers to engage in retrospective sense-making. This concept originates in Weick's

\footnotetext{
${ }^{2}$ These take the form of unfavourable analyst reports and credit ratings, and ultimately, negative share price movements on the one hand; and loss of stakeholder support and social legitimacy on the other hand. As corporate reporting takes place in a social context, it is influenced by social norms and rules. This requires a shift to substantive rationality which is concerned with ideals, goals and ends which are pursued for their own sake, such as equality, justice, and freedom (Weber, 1968). Substantive rationality addresses mainly social and environmental issues, such as fair trade, equality in the workplace, and pollution. Substantive rationality is a rationality of ends which involves applying appropriate reason to achieve these ends. Thus, impression management is regarded as a managerial attempt to gain or restore social legitimacy by aligning the company's norms and values with those of society by decoupling or symbolic management. In this case, impression management constitutes an inconsistency between the firm's actual and professed norms and values.
} 
(1995) work on organisational sense-making and refers to the interpretation of events that have already occurred. Managers may thus use corporate annual report documents to proactively shape shareholders' and stakeholders' perceptions of organisational outcomes and events (impression management) and/or to retrospectively provide an account of events (retrospective sense-making). Retrospective sense-making is contrary to the goal-seeking perspective of economic rationality which is generally assumed to drive managerial behaviour and thus corporate narrative reporting. The conditions of 'ex post' accountability in corporate annual reporting, which is characterised by managers anticipating readers' reactions, may give rise to impression management and/or retrospective sense-making. Impression management may take the form of either presenting an inaccurate view of organisational outcomes (self-presentational dissimulation) and/or an accurate (i.e., consistent with organisational performance as reported in the financial statements), but favourable, view of organisational outcomes. Figure 2 illustrates the impact of accountability on managerial corporate annual reporting behaviour as impression management and/or retrospective sense-making. 


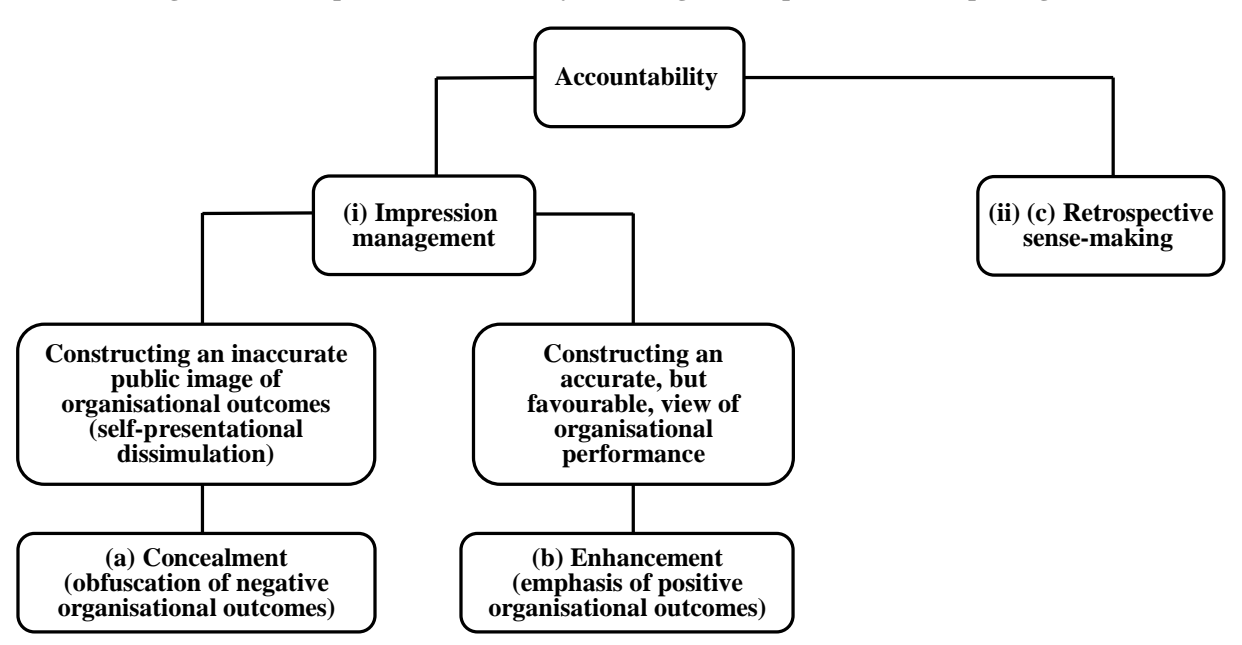

\subsection{Impression construction, self-presentational dissimulation and the psychological dimension of word use}

We assume that the concerns of information providers about the consequences of the information recipients' actions will manifest themselves verbally. We focus on the linguistic indicators of the psychological processes underlying the construction of images which are inconsistent with one's self-concept. Previous studies have focused on specific impression management strategies adopted to obfuscate negative organisational outcomes, thereby constructing an inaccurate public image of organisational outcomes, in particular reading ease manipulation and rhetorical manipulation (Merkl-Davies and Brennan, 2007).

Social psychology is a discipline that uses scientific methods "to understand and explain how the thoughts, feelings and behaviours of individuals are influenced by the actual, imagined or implied presence of other human beings" (Allport, 1954, p. 5). The underlying assumption is that unobservable processes, such as thoughts, feelings, and beliefs are the psychological dimension of social behaviour and that these can be 
inferred from behaviour. Behaviour includes actions and non-verbal behaviour, such as body language, facial expressions, gestures, and language.

The method of analysis chosen is based on the assumption that the way people express themselves conveys psychological information (Pennebaker et al., 2003). Language is viewed as a psychological marker which can be analysed by counting the occurrence of specific words and word categories which capture the way content is expressed (Newman et al., 2003). It involves word counts of grammatical features, such as personal pronouns (e.g., I, my, mine) and conjunctions (e.g., and, but, although) or psychologically derived linguistic dimensions, such as emotion words (e.g., wonderful, exciting) or achievement-related words (e.g., try, goal, win). Word count strategies "are based on the assumption that the words people use convey psychological information over and above their literal meaning and independent of their semantic context" (Pennebaker et al., 2003, p. 550).

Pennebaker et al., (2003) observe that three classes of word categories are implicated in deception (what we call self-presentational dissimulation) - pronoun use, emotion words and markers of cognitive complexity (e.g., exclusive words). Newman et al., (2003) find a relatively consistent linguistic profile for deception, based on five word categories: (1) first person singular pronouns (liars avoid statements of ownership, disassociate themselves from the text), (2) third person pronouns, (3) negative emotion words (arising from discomfort and guilt associated with lying), (4) exclusive words (associated with cognitive complexity) and (5) motion verbs (negatively associated with cognitive complexity) (liars tell less complex stories). Verbosity, i.e., the amount of words used, is also found to be a predictor of deception (lying is associated with less detail, thus resulting in shorter communication) (DePaulo et al., 2003; Burgoon et al., 2003; Vrij at al., 2000).

Following this research, we employ a content analysis approach which is based on the linguistic indicators of self-presentational dissimulation in the form of six word categories, namely (1) word count, (2) first person pronouns, (3) third person pronouns, (4) positive emotion words, (5) negative emotion words, and (6) words relating to underlying complex cognitive processes (Burgoon et al., 1996; 2003; Newman et al., 2003; Pennebaker et al., 2003). These convey psychological 
information on the underlying emotional state of individuals engaged in constructing public images which are inconsistent with their self-concept. They "are the result of anxiety, negative emotional states, and cognitive demand" (Carlson et al., 2004, p. 7) which go hand-in-hand with conveying "messages and information knowingly transmitted to create a false impression or conclusion" (Burgoon and Nunamaker, 2004, p. 1). The intention is to construct an instrument measuring the verbal manifestations of managerial concern about the impact of narrative disclosures on information recipients' actions.

However, psychology research based on word use shows the content categories used to analyse self-presentational dissimulation to be indicative of a variety of other psychological processes and behaviour, including gender, and physical and emotional health (Campbell and Pennebaker, 2003). What is more, pronouns and adjectives (with both positive and negative connotations) are amongst the most commonly used textual elements in content analysis (Macnamara, 2003, p. 17) to analyse a variety of phenomena, including impression management. Baker and Kare (1992), Kohut and Segars (1992), Rutherford (2003), Clatworthy and Jones (2006), and Li (2008) use document length as a proxy for reading difficulty. Abrahamson and Park (1994), Abrahamson and Amir (1996), Smith and Taffler (2000), Lang and Lundholm (2000), Clatworthy and Jones (2003), Rutherford (2005), Henry (2006, 2008), Matsumoto et al. (2006), and Davis et al. (2008) use positive and negative keywords as a proxy for the enhancement of positive organisational outcomes (managerial optimism and pessimism).

We therefore argue that the content categories used as proxies for self-presentational dissimulation can also be interpreted as indicators of managerial enhancement of positive organisational outcomes or managerial retrospective sense-making. Bloomfield (2008) puts forward a similar argument in his discussion of Li's (2008) paper on impression management in the form of reading ease manipulation. He states that word and sentence length and document length may be interpreted as indicators of the complexity of the news to be described, rather than obfuscation by means of reading difficulty, with negative financial performance requiring more complex and detailed explanations than positive financial performance. 


\section{HYPOTHESES, DATA AND METHOD}

This section discusses the research questions, the research method, including selection of the sample, data sources used, measurement of the independent variables, and the statistical methods applied in analysing the data.

\subsection{Hypotheses}

The use of impression management in a corporate reporting context has been found to be causally linked to various firm characteristics, including organisational outcomes, firm size, and industry sector classification. Research in social psychology suggests that the strength of organisational actors' motivations to engage in impression management depends on (1) the goal-relevance of the impressions (including the maximisation of social and material outcomes, the maintenance and enhancement of self-esteem, and identity creation) (2) the value of the desired outcomes, and (3) the discrepancy between one's desired and current social image (Leary and Kowalski, 1990). Negative organisational outcomes can thus be regarded as a trigger for organisational actors to engage in impression management. We expect firms with negative organisational outcomes to be more likely to present a public image of organisational performance which is inconsistent with the managerial view of organisational performance than firms with positive organisational outcomes. Therefore, we expect self-presentational dissimulation to be directly associated with negative organisational outcomes.

$\mathrm{H}_{1 \mathrm{a}}$ : Firms reporting negative organisational outcomes in their financial statements are more likely to engage in self-presentational dissimulation than firms reporting positive organisational outcomes. 
However, managers may use corporate annual report documents to present an accurate (i.e., consistent with organisational performance as reported in the financial statements), but favourable, view of organisational outcomes (enhancement of positive organisational outcomes). Thus, managers are inclined to emphasise positive organisational outcomes, regardless of their financial performance. We express this hypothesis in the null form.

$\mathrm{H}_{1 \mathrm{~b}}$ : There is no difference in impression management by means of enhancement of positive organisational outcomes between firms reporting positive organisational outcomes and firms reporting negative organisational outcomes in their financial statements.

What is more, the accountability context of corporate annual reporting may prompt managers to engage in retrospective sense-making manifesting itself in "ex post explanations or restatements of organizational outcomes and events" (Aerts, 2005, p. 497). Under conditions of ex post accountability, we thus expect an increase of retrospective sense-making in the case of negative organisational outcomes.

$\mathrm{H}_{1 \mathrm{c}}$ : Firms reporting negative organisational outcomes in their financial statements are more likely to engage in retrospective sense-making than firms reporting positive organisational outcomes.

The goal relevance of impressions also depends on the publicity of the individual's behaviour and on the individual's dependency on others for valued outcomes. Publicity is “a function of both the probability that one's behavior will be observed by others and the number of others who might see or learn about it" (Leary and Kowalski, 1990, p. 38). If an individual depends on others for valued outcomes, the impressions that individuals make on others become more important and the individual's motivation to engage in impression management becomes stronger. As large firms are more in the public eye than small firms in the sense that they have a higher analyst following and a wider media exposure, they may be more likely to present a public image of organisational outcomes inconsistent with the managerial view of organisational outcomes. Conversely, large firms are subject to greater 
scrutiny and are therefore more likely to be found out and sanctioned for engaging in self-presentational dissimulation and impression management (Abrahamson and Park, 1994). Therefore, we do not make any predictions concerning the direction of association with firm size.

$\mathrm{H}_{2 \mathrm{a}}$ : There is no difference in self-presentational dissimulation between firms of different sizes.

$\mathrm{H}_{2 \mathrm{~b}}$ : There is no difference in impression management by enhancement between firms of different sizes.

$\mathrm{H}_{2 \mathrm{c}}$ : There is no difference in the sense-making activities of managers between firms of different sizes.

We further assume that there is no difference in the impression management behaviour and the sense-making behaviour of firms belonging to different industries.

$\mathrm{H}_{3 \mathrm{a}}$ : There is no difference in self-presentational dissimulation between firms in different industries.

$\mathrm{H}_{3 \mathrm{~b}}$ : There is no difference in impression management by enhancement between firms in different industries.

$\mathrm{H}_{3 \mathrm{c}}$ : There is no difference in the sense-making activities of managers between firms in different industries.

\subsection{Population and sample}

The population from which the sample is selected comprises all UK domiciled companies listed on the London Stock Exchange on 30 April 2004 (1,983 companies). The aim of sample selection is to derive a sample comprising a variety of industries and firm sizes. The companies were first grouped into sectors, based on the Dow Jones Market Sector classifications. In order to generate a large enough sample, the three sectors with the highest number of companies were selected for analysis (Financial Services companies are excluded due to their unique features). The three resulting sectors are Consumer Cyclical (CYC; $\mathrm{n}=360)$, Technology (TEC; $\mathrm{n}=193$ ), 
and Industrial (IDU; $\mathrm{n}=331$ ). ${ }^{3}$ An initial sample of 93 firms was then selected comprising 31 companies from each of the three industries. The initial sample size of 93 was chosen as sufficiently large to permit statistical testing. These were selected using systematic sampling to ensure heterogeneity of firm sizes. For this purpose, the companies in each industry sector were ranked according to size (end of year market capitalisation 2002 in Emillion) and sample companies were chosen at regular sampling intervals throughout the size ranges. The sampling interval is the ratio $N / n$, i.e., where $N$ represents the population and $n$ the desired sample size (i.e., 31 ) in each industry sector. The full selection process is documented in Table 1.

(Take in Table 1 about here)

The sample size of 88 is small. Other than Li (2008), most prior papers in this field have small sample sizes, due to labour-intensive process of collecting, preparing and analysing textual data.

\subsection{Data sources and textual analysis software}

The annual report chairman's statement is a tried and tested medium for the investigation of impression management in narrative corporate report sections (Jones, 1988; Smith and Taffler, 1992a, 1992b, 1995, 2000; Clatworthy and Jones, 2001, 2006; Sydserff and Weetman, 2002; Courtis, 1998, 2004a). Its relatively short length makes it particularly suitable for content analysis.

The chairmen's statements were obtained by downloading the 2002 annual reports in $p d f$ format. These would have been the first annual reports post-Enron when financial reporting and the quality of accounting information were the subject of considerable public attention worldwide. After deleting photographs and their captions, images, charts, graphs, tables, forms of address (Dear shareholder), and greeting (Yours faithfully), the chairmen's statements were converted into computer readable text format.

\footnotetext{
3 The industry classification Consumer Cyclical includes firms operating in the subsectors of advertising, entertainment and leisure, publishing, clothing and fabrics, etc.; Industrial includes firms operating in the subsectors of building materials, pollution control/waste management, electrical components and equipment, etc.; Technology includes firms operating in the subsectors of aerospace and defence, computers, office equipment, etc.
} 
We use Linguistic Inquiry and Word Count (LIWC), an automated text analysis program developed by psychologists for the purpose of analysing linguistic style, to measure self-presentational dissimulation. Its external validity has been extensively tested (Pennebaker and Francis, 1996). The program analyses written samples of text on a word-by-word basis and calculates the number of words that match pre-defined word categories which are then hierarchically subdivided into 70-80 dimensions (depending on the version of the software used) (see Pennebaker et al., 2007 for full details of how the software operates). ${ }^{4}$ This program has been used in numerous studies to examine linguistic manifestations of psychological processes and behaviour, such as personality characteristics of US presidential candidates (Slatcher et al., 2007), demographic differences, such as age and gender (Pennebaker and Stone, 2003), emotional issues, such as bereavement and depression (Gill and Oberlander, 2003; Pennebaker and King, 1999), and self-presentational dissimulation (Newman et al., 2003; Burgoon et al., 2003; Hancock et al., 2008).

\subsection{Measurement of dependent variables}

Measurement of the three dependent variables in this research is presented below.

\subsubsection{Self-presentational dissimulation}

We adapt a content analysis methodology based on the linguistic style associated with self-presentational dissimulation developed by Newman et al. (2003). Research in psychology finds the texts of individuals who engage in deception to show the following linguistic characteristics: (1) They are shorter (DePaulo et al., 2003; Burgoon et al., 2003; Vrij et al., 2000), (2) they contain fewer self-references (Newman et al., 2003), (3) they contain fewer references to others (Newman et al., 2003), (4) they contain more positive emotion words (Newman et al., 2003; Burgoon et al., 2003; Zhou et al., 2004), (5) they contain more negative emotion words (Newman et al., 2003; DePaulo et al., 2003), and (6) they contain fewer words indicative of cognitive complexity (Newman et al., 2003). Deception goes hand-inhand with providing less detail in the account of events. As the use of self-references in the form of first-person is a "subtle proclamation of one's ownership of a

\footnotetext{
${ }^{4}$ For example, the word 'optimistic', falls into five of the 70-80 dimensions, namely 'optimism', 'positive emotion', 'overall affect,' 'words longer than six letters' and 'adjective'.
} 
statement" (Newman et al., 2003, p. 666), individuals engaged in deception avoid the use of self-references as a way of distancing themselves from their stories and to avoid taking responsibility for their behaviour. The increased use of emotion words is a reflection of the discomfort experienced when engaging in deception (Newman et al., 2003, p. 666). Finally, deception consumes cognitive resources which results in less complex stories (Newman et al., 2003, p. 666). This manifests itself, amongst others, in a less complex sentence structure, less causation words (e.g., because, cause, effect), and fewer words expressing the ability to think, learn and understand (e.g., think, know, consider).

This is the first study applying Newman et al.'s (2003) content analysis approach in a corporate reporting context. Gupta and Skillicorn (2006, p. 2), who use the approach to analyse a large corpus of Enron email messages, find that "the model captures ... messages in which there seems to be a dichotomy between the overt meaning of the email and the mindset of the sender". They conclude that it captures 'spin', i.e., "the attempt by authors to convey something they themselves do not (quite) believe". Newman et al.'s (2003) content analysis approach is based on the behaviour of individuals, whereas the content of corporate narrative documents is the result of decision behaviour of a group of people, primarily the firm's management (Clarke and Murray, 2000). The assumption that the behaviour of individuals and groups of individuals is the same is open to question.

For the six linguistic indicators of self-presentational dissimulation we make use of four dimensions from $L I W C$, (1) Word count (LIWC: log word count $\left.{ }^{5}\right)$, (2) positive emotion words (LIWC: positive emotion), (3) negative emotion words (LIWC: negative emotion), and (4) cognitive complexity (LIWC: cognitive processes). We then create custom dictionaries for the two remaining linguistic indicators, namely (5) self-reference (this custom dictionary contains three word categories - first person plural pronoun (i.e., 'we', 'us', 'our', 'ours', 'ourselves'), 'the Group', and the name of the company), and (6) reference to others (this custom dictionary contains four

\footnotetext{
${ }^{5}$ Because of the skewness in the number of words across firms and some extreme values we use the natural logarithm, rather than the raw word count.
} 
words - 'industry', 'sector', 'competitor', and 'rival'). ${ }^{6}$ Following Newman et al., (2003) and Slatcher et al., (2007) the measures for each indicator are subsequently converted to $z$ scores. A $z$ score is a standardised measure which is derived by considering the distance in terms of standard deviation from the mean of the raw score. The individual $z$ scores are summed using the following algorithm:

Self-presentational dissimulation $=-\mathrm{zWord}$ Count $-\mathrm{zSelf}$-reference $-\mathrm{zReference} \mathrm{to}$ others $+\mathrm{zPositive} \mathrm{Emotion}+\mathrm{zNegative} \mathrm{Emotion}-\mathrm{z}$ Cognitive Complexity. ${ }^{7}$

We assume that the higher the score, the more likely it is that a company is portraying a public image of organisational outcomes which is inconsistent with the managerial view of organisational outcomes. Table 2 outlines the six linguistic indicators of selfpresentational dissimulation for chairmen's statements, their abbreviation, examples of their application in practice, data sources and measurement.

(Take in Table 2 about here)

Table 3 provides the descriptive statistics for the six linguistic indicators and the summary $z$ score for self-presentational dissimulation for our sample of UK chairmen's statements. Its shows marked differences in mean values between positive emotion words $(3.314 \%)$ and negative emotion words $(0.857 \%)$. This suggests that, on average, chairman's statements tend to contain four times as many positive emotion words (e.g., exciting, win) than negative emotion words (e.g., difficult, disappointing, loss). This has been referred to as the 'Pollyanna effect' (Hildebrandt and Snyder, 1981). However, only association tests can ascertain whether this prevalence to 'enhance the story' (Courtis, 2004a, p. 293) occurs regardless of financial performance.

(Take in Table 3 about here)

\footnotetext{
${ }^{6}$ It is not meaningful to combine the output for all six indicators of self-presentational dissimulation into a single score because first of all, they are on different scales, i.e., the Word Count measure is an absolute measure and the remaining variables are percentage measures. What is more, their direction of association is not in the same direction.

${ }^{7} Z$-scores for each linguistic indicator are calculated by subtracting the sample mean $\left(\mu_{\mathrm{x}}\right)$ from each value $(\mathrm{x})$ and then dividing by the standard deviation $\left(\sigma_{\mathrm{x}}\right)$, i.e. $\mathrm{z}_{\mathrm{x}}=\left(\mathrm{x}-\mu_{\mathrm{x}}\right) / \sigma_{\mathrm{x}}$.
} 


\subsubsection{Impression management by means of enhancement}

If managers use corporate narratives to provide useful incremental information, then positive organisational outcomes should be associated with the use of positive key words and negative organisational outcomes with the use of negative key words (Abrahamson and Amir, 1996; Henry, 2006; Davis et al., 2008). However, if managers use corporate annual report documents to enhance positive organisational outcomes, then we expect to see no difference in the use of positive key words between firms reporting positive organisational outcomes and firms reporting negative organisational outcomes (Smith and Taffler, 2000; Rutherford, 2005). We use the LIWC content categories of positive and negative emotion words which capture words with positive and negative connotations. ${ }^{8}$

\subsubsection{Retrospective sense-making}

Sense-making is assumed to manifest itself in an increase in cognitive complexity and document length. Bloomfield (2008) uses document length as a proxy for cognitive complexity. We use both document length (word count) and the LIWC content category 'cognitive processes' which is characterised by causation and insight words (e.g., because, think, know).

The linguistic indicators used as proxies for self-presentational dissimulation, impression management by means of enhancement, and retrospective sense-making (dependent variables), and their expected direction of association with organisational outcomes, are summarised in Table 4.

(Take in Table 4 about here)

\subsection{Data for independent variables}

Three independent variables are tested in this research: financial performance in terms of organisational outcomes, firm size, and industry classification. The database Thomson One Banker-Analytics is used to download all the financial variables from

\footnotetext{
${ }^{8}$ Alternatively, if managers use corporate annual report documents to obfuscate negative organisational outcomes, then we expect to see no difference in the use of negative key words between firms reporting positive organisational outcomes and firms reporting negative organisational outcomes.
} 
1999 to 2002, including data for the financial performance variables (i.e., total assets, total sales, income before taxation and interest, the firm size variable (i.e., end of year market-capitalisation) and the Dow Jones industry classification.

\subsubsection{Organisational outcomes}

Four different measures that distinguish positive and negative organisational outcomes reported in the financial statements are used. Prior research predominantly focuses on firm-specific and transitory aspects of financial performance, most commonly positive/negative percentage change in earnings (Courtis, 1998; Subramanian et al., 1993). In this study, two measures based on assets and sales which capture more permanent aspects of financial performance in relation to the firm's competitive environment are also used.

Prior impression management research has used three categories of financial performance measures, namely (1) accounting measures that are predominantly percentage change in net income (Adelberg, 1979; Courtis, 1995, 1998, 2004a; Jones, 1988; Sydserff and Weetman, 2002; Rutherford, 2003; Li, 2008), (2) market-based measures (Cassar, 2001), and (3) bankruptcy/survival measures (Smith and Taffler, 1992a, b). Following Subramanian et al. (1993), Courtis (2004a) and Smith and Taffler (1992a, b), we treat financial performance as a dichotomous variable, i.e., either positive or negative organisational outcomes. We base these dummy variables on four accounting measures which reflect different types of organisational outcomes. These are summarised in Table 5.

Profit or Loss indicates whether the firm's income (before interest and taxation) is either positive or negative, taking the value of zero if an absolute net loss is reported and a value of one otherwise. In this context, it is generally assumed that managers normally seek to avoid reporting a loss (Hayn, 1995). Research in earnings management has provided substantial evidence concerning such benchmark beating in firms. In this study it is assumed that managers engage in self-presentational dissimulation and retrospective sense-making when expectations cannot be achieved.

Earnings Increase or Decrease indicates whether the change in earnings between the two years in question (2001 and 2002) is either positive or negative. In this case, 
managers are assumed to seek to report results that improve upon last year's performance (Burgstahler and Dichev, 1997; Degeorge et al., 1999). The variable takes a value of zero if there is a decrease in earnings, and a value of one otherwise.

Annual earnings may be influenced by a number of non-contemporaneous factors. These would include corrections to past valuations and the prudent recognition of current value-increasing activities whose income effect is deferred until its eventual certain realisation in future periods. Therefore, we also consider a broader accountingbased indicator of performance that provides a global measure of current activities, i.e., sales. Revenue is a key measure of a firm's economic activity. In prior research, firm performance has been operationalised as sales growth rate relative to its industry (Powell, 1996; Covey et al., 2006). Investment analysts use revenue to proxy the entity's current level of economic activity relative to past levels, and with its competitors as part of their assessment of the firm's financial performance. In this context, it is assumed that negative sales growth and lower sales growth than the firm's competitors represent missed targets. Sales growth rate is reflected in the dummy variable Relative Sales Increase or Decrease, which is an indicator of either positive or negative growth in the total sales of a firm from 2001 to 2002, relative to the rate of change in output in the overall industry. The variable takes a value of zero if the percentage change in Sales is below the industry average, and one otherwise.

Finally, Relative Firm Growth captures the longer-term growth of a firm relative to its industry by averaging the growth in both sales and total assets over a four year period (1999-2003) and then adjusting for the industry mean. This is also treated as a 0,1 indicator, in this case taking the value of zero if firm growth is below the industry average and one otherwise.

(Take in Table 5 about here)

Table 6 shows the number of companies in the sample reporting positive and negative organisational outcomes across the four proxy outcomes measures. It can be seen that there is an approximate 3:2 split between the two groups across all four measures.

(Take in Table 6 about here) 


\subsubsection{Firm size}

Table 7 shows the descriptive statistics of firm size, measured as the natural logarithm of market capitalisation in 2002, for the whole sample. The market values themselves range from $£ 0.164 \mathrm{~m}$ to $£ 6,124 \mathrm{~m}$ with median value of $£ 43.38 \mathrm{~m}$.

(Take in Table 7 about here)

\subsubsection{Industry}

Impression management may be affected by the industry in which the company operates (Aerts, 2005). In order to control for variability in the three dependent variables across industries, the sample was divided into three broad industry sectors based on the Dow Jones Market Sector classifications (Consumer Cyclical, Technology, and Industrial).

\subsection{Statistical analysis}

We use ordinary linear regressions to examine the relationship between the three dependent variables and firm characteristics. The specification of the model is as follows:

(a) Self-presentational

dissimulation

(b) Impression $\quad=\quad \beta_{0}+\beta_{1}$ (positive/negative organisational outcomes dummy) management $\quad+\beta_{2}$ (Firm size $)+\beta_{3}$ (Industry sector dummies $)+u_{1}$

(c) Retrospective (unexplained residual)

sense-making

\section{RESULTS}

We test the three hypotheses set out earlier on the relationship between (a) selfpresentational dissimulation (i.e., the summary $z$-score), (b) impression management by means of enhancement, and (c) retrospective sense-making and (i) organisational outcomes, (ii) firm size, and (iii) industry. Table 8 presents the results of regressing the summary $z$-score on the four different measures of financial performance (Table 8, column 1). In all the regressions firm size and industry classification are included as 
control variables. Our findings do not support hypothesis $\mathrm{H}_{1 \mathrm{a}}$ which predicts that firms reporting negative organisational outcomes engage self-presentational dissimulation which entails constructing a public image of managerial actions and events that is inconsistent with the way management views these actions and events. However, we find that the chairmen's statement of firms operating in the Industrial sector use significantly less self-presentational dissimulation (for the four organisational measures the coefficients are respectively: $-2.34 * * ;-2.50^{* *} ;-2.64 * * *$; -0.19) than firms operating in the Consumer Cyclical and the Technology sector, a finding that we cannot currently explain.

In order to investigate the complementary hypotheses regarding managerial corporate annual reporting behaviour (in the form of impression management by means of enhancement and in the form of retrospective sense-making), we also regress each linguistic indicator on the four measures of financial performance separately (Table 8, columns 2-7). ${ }^{9}$ We find that firms which report negative organisational outcomes use significantly less positive emotion words (for the four organisational measures the coefficients are respectively: $2.69 * * * ; 2.89 * * * ; 0.68 ; 0.13)$ and significantly more negative emotion words (coefficients $-2.79 * * * ;-2.99 * * * ;-3.26 * * * ;-4.55^{* * *}$ ) than firms which report positive organisational outcomes. This suggests that managers do not use corporate narrative annual report sections to present an inaccurate view (i.e., inconsistent with organisational performance as reported in the financial statements) of organisational outcomes, but rather to explain or reinforce "the impression created elsewhere by raw figures" (Courtis, 1995, p. 14). ${ }^{10}$ This finding supports hypothesis $\mathrm{H}_{1 \mathrm{~b}}$ which predicts no difference between impression management by means of enhancement between firms reporting positive and negative organisational outcomes.

Further, the chairmen's statements of firms reporting negative organisational outcomes are characterised by more linguistic indicators of cognitive complexity than those of firms reporting positive organisational outcomes (coefficients -3.51***; $\left.0.61 ;-2.10^{* *} ;-3.13^{* * *}\right)$. This suggests that explaining losses and negative sales

\footnotetext{
${ }^{9}$ We also run the same regressions using the individual $z$-scores for the six linguistic indicators. The results are not reported, but are of a similar magnitude and statistical significance to those of the unstandardised linguistic indicators reported in Table 8 (columns 2-7).

${ }^{10}$ It also refutes the 'Pollyanna effect' (Hildebrandt and Snyder, 1981, p. 6) which suggests that managers introduce positive bias into corporate narrative documents, irrespective of financial performance.
} 
growth and negative firm growth compared to competitors requires more cognitive resources. This manifests itself semantically in more causation words and grammatically in a more complex sentence structure than explaining profits, and positive sales growth and positive firm growth compared to competitors. This finding supports the retrospective sense-making hypothesis $\mathrm{H}_{1 \mathrm{c}}$

This suggests that in an annual reporting context characterised by "ex post accountability" (Aerts, 2005, p. 497), "overall financial performance [can] be conceived as a primary content variable around which (and not necessarily about which) a number of different accounting (and non-accounting) stories [can] be built" (ibid, p. 496). Thus, corporate annual report documents may not be the outcome of proactive, purposeful, and goal directed managerial decision-making (prospective rationality), but rather the result of retrospective sense-making (retrospective rationality) characterised by managers making "interpretive readings of an organisational situation" (Boland, 1993, p. 125) under conditions of accountability. This manifests itself in "ex post explanations or restatements of organizational outcomes and events" (Aerts, 2005, p. 497).

In contrast to Bloomfield (2008), we find positive financial performance (in the form of sales increase and positive firm growth relative to sector average) to result in an increase in document length (measured as word count) (coefficients $2.92 * * * ; 2.04 * *$ ). This indicates that firms which outperform their competitors in terms of sales and asset growth provide longer corporate narrative annual report documents than firms whose sales and assets growth is worse than the sector. Bloomfield (2008) regards descriptions of negative financial performance to be more complex and thus lead to an increase in document length. However, our results suggest the opposite, namely that managers have the tendency to enhance positive organisational outcomes by describing them in more detail than negative organisational outcomes. This finding contradicts the retrospective sense-making hypothesis $\mathrm{H}_{1 \mathrm{c}}$ and supports the impression management by enhancement hypothesis $\mathrm{H}_{1 \mathrm{~b}}$.

Further, firms operating in the technology sector (coefficients $2.36^{* *} ; 2.47^{* * ;}$; $2.36^{* *}$; $2.79^{* * *}$ ) and the industrial sector (coefficients $3.87^{* * *} ; 4.15^{* * *} ; 4.15^{* * *} ; 4.23^{* * *}$ ) also provide more cognitively complex chairmen's statements than firms operating in 
the consumer cyclical sector. This may be an indication of the greater complexity of the subject matter compared with firms operating in the consumer cyclical sector. Thus, hypothesis $\mathrm{H}_{3 \mathrm{c}}$ is not supported, with evidence of significant differences in use of the linguistic cognitive complexity indicator by industry sector.

Further, we find the chairmen's statements of large firms to contain more selfreferences (coefficients $4.13^{* * *} ; 4.26 * * * ; 4.18^{* * * ;}$ 4.13***), more positive emotion words (coefficients $1.35 ; 2.16^{* *} ; 2.37^{* *} ; 2.45^{* *}$ ) and less negative emotion words (coefficients $-1.40 ;-2.24 * * ;-2.12 * * ;-1.98 * *$ ) than those of small firms. This suggests that large firms may have a greater tendency to use their corporate annual report documents as impression management vehicles by putting the best part of themselves into public view (Leary and Kowalski, 1990, p. 40) than small firms. Thus, our findings support hypothesis $\mathrm{H}_{2 \mathrm{~b}}$. The increased use of the company name and the first person plural, combined with the tendency to use rather more words with positive than negative connotations, suggests that large firms may use their chairmen's statements more for brand-building than small firms.

(Take in Table 8 about here)

In summary, our results suggest that firms do not use chairmen's statements to portray an inaccurate image of organisational outcomes (self-presentational dissimulation). We find that large firms are more likely to portray an accurate (i.e., consistent with organisational performance as reported in the financial statements), albeit favourable image of organisational outcomes. Further, we find that negative organisational outcomes do not prompt managers to engage in self-presentational dissimulation, but rather to engage in retrospective sense-making by means of "drawing together a series of events in order that they make sense in relation to one another" (Crossley, 2000, p. 535). This manifests itself linguistically in the form of a more complex grammatical sentence structure and more causation and insight words (e.g., because, think, know).

\section{SUMMARY AND CONCLUSION}

In this study we argue that the economic view of impression management is reductionist in the sense that it treats managerial corporate annual reporting behaviour 
characterised exclusively by prospective rationality and driven by utility maximisation. As corporate reporting takes place in a social context, accounting research may benefit from the use of social psychology theories. We conceptualise impression management as a social bias caused by managers anticipating an inquiry by shareholders and stakeholders who evaluate their actions and decisions. This causes managers to counteract undesirable consequences of information releases by engaging in impression management. We employ a content analysis approach pioneered by psychology research which focuses on the linguistic indicators of the psychological processes underlying self-presentational dissimulation to analyse 93 UK chairmen's statements of listed firms. Our results suggest that the accountability function of corporate reporting does not prompt managers to provide a public account of organisational outcomes which is inconsistent with how management may perceive them (self-presentational dissimulation), but to provide explanations of their decisions and actions as a way of making sense of them. This is in line with Aerts (2005) who finds that the accountability function of corporate annual reporting causes managers to engage in retrospective sense-making. Further, results suggest that impression construction in corporate annual report documents entails presenting an accurate (i.e., consistent with organisational performance as reported in the financial statements), albeit favourable view of the firm and financial performance.

\subsection{Strengths and limitations of the paper}

This paper introduces a social psychology perspective to corporate annual reporting and impression management. We use psychology theories and apply a content analysis approach developed by psychology research for measuring deception. The content analysis method uses findings based on the behaviour of individuals (Newman et al., 2003). The assumption that the behaviour of individuals and groups of people, such as the firm's management team, which tends to author corporate narrative reports (Clarke and Murray, 2000), is the same is open to question. Like any other quantitative content analysis approaches, the method used in this study combines the advantages of automatic generation of content scores, namely ease of application, objectivity, reliability, and speed, with psychological validity. However, the downside of this approach is that words are analysed regardless of their context. 


\subsection{Implications of the research}

The results suggest that corporate reporting is a more complex and multi-dimensional process than acknowledged by the prior literature. Corporate narrative documents may not only serve a vehicle for transmitting (biased) information and/or as a means of forging relationships with shareholders and stakeholders, but also to provide an account of organisational outcomes as a result of managerial actions and events. This confirms Gibbins et al. (1990, p. 130) findings that different disclosure positions, i.e., "the shared meanings and understandings of the role of disclosure among managers in a particular firm' co-exist for different kinds of disclosures within the same firm. Thus, corporate annual reporting may not only be understood from a behavioural perspective involving managers responding to objectively determined stimuli inherent in the accountability framework, but also from a symbolic interaction perspective which involves managers retrospectively making sense of organisational outcomes and events. These positions are based on different views regarding the ontological nature of human behaviour and actions (Johnson et al., 2006) as either purposive or as interpretive. If the ontological status of human behaviour is regarded as purposive, then corporate reporting functions as "a technical device for coping with an objective world, rationally fostering efficiency, order and stability" (Covaleski et al., 1985, p. 278). Alternatively, if the ontological status of human behaviour is regarded as interpretive, then corporate reporting constitutes a symbolic activity during which managers engage in social reality creation and "in so doing, ... give meaning to their ongoing stream of experience" (Boland and Pondy, 1983, p. 223).

The sense-making aspect in corporate communication may be further investigating by comparing the way managerial actions, organisational outcomes, and events are portrayed in more immediate communication vehicles, such as corporate press releases, takeover documents, and prospectuses, and in corporate narrative documents which serve an accountability function, such as corporate annual report documents.

\subsection{Concluding comment}

Accounting researchers tend to view corporate report documents primarily though the lens of economics. This leads to a reductionist view of corporate reporting and impression management as characterised by prospective rationality and driven by utility maximisation. This paper provides a social psychology perspective which puts 
the accountability context of corporate reporting at the centre of analysis. Conditions of ex post accountability may result in impression motivation arising from the managerial anticipation of the feedback effects of information and/or give rise to the retrospective framing of organisational outcomes. Our findings suggest that impression construction does not involve a disparity between managerial views of organisational performance and the view portrayed publicly in corporate reports (selfpresentational dissimulation). Rather, impression construction entails presenting an accurate (i.e., consistent with organisational performance as reported in the financial statements), albeit favourable, view of the firm. Further, corporate annual report sections may not be primarily used to shape outsiders' perceptions of organisational outcomes, but rather, to construct an account of organisational outcomes. In this respect, corporate narratives, like conventional narratives, such as stories as myths, may serve to "organise our experience and our memory of human happenings" (Bruner, 1991, p. 4). 


\section{References}

Abrahamson, E. and Amir, E. (1996), “The information content of the president's letter to shareholders", Journal of Business Finance and Accounting, Vol. 23 No. 8, pp. 1157-1182.

Abrahamson, E. and Park, C. (1994), "Concealment of negative organizational outcomes: an agency theory perspective", Academy of Management Journal, Vol. 37 No.5, pp. 1302-1334.

Adelberg, A.H. (1979), "Narrative disclosures contained in financial reports: means of communication or manipulation', Accounting and Business Research, Vol. 10 (Summer), pp. 179-189.

Aerts, W. (1994), "On the use of accounting logic as an explanatory category in narrative accounting disclosures", Accounting, Organizations and Society, Vol. 19 No. 4/5, pp. 337-353.

Aerts, W. (2001), "Inertia in the attributional content of annual accounting narratives", The European Accounting Review, Vol. 10 No. 1, pp. 3-32.

Aerts, W. (2005), "Picking up the pieces: impression management in the retrospective attributional framing of accounting outcomes", Accounting, Organizations and Society, Vol. 30, pp. 493-517.

Allport, G.W. (1954). The historical background of social psychology. In G. Lindzey, and E. Aronson, (Eds.), Handbook of Social Psychology, Vol. 1 No. 3, pp. 1-46.

Baird, J.E. and Zelin, R.C. (2000), "The effects of information ordering on investor perceptions: An experiment utilizing presidents' letters", Journal of Financial and Strategic Decisions, Vol. 13 No. 3, pp. 71-81.

Baker, H.E. and Kare, D.D. (1992), "Relationship between annual report readability and corporate financial performance", Management Research News, Vol. 15 No. 1, pp. 1-4.

Beattie, V. and Jones, M. (2000), "Impression management: the case of inter-country financial graphs", Journal of International Accounting, Auditing and Taxation, Vol. 9 No.2 (June), pp.159-183.

Bettman, J. and Weitz, B. (1983), "Attributions in the boardroom: causal reasoning in corporate annual reports", Administrative Science Quarterly, Vol. 28, pp. 165183. 
Bloomfield, R. (2008), "Discussion of 'Annual report readability, current earnings, and earnings persistence"”, Journal of Accounting and Economics, Vol. 45 Nos. 2-3, pp. 248-252.

Boland, R.J. (1993), "Accounting and the interpretive act", Accounting, Organizations and Society, Vol. 18 No. 2/3, pp. 125-146.

Boland, R.J., and Pondy, L.R. (1983), "Accounting in organizations: a union of natural and rational perspectives," Accounting Organizations and Society, Vol. 8 No. 2/3, pp. 223-234.

Bruner, J. (1991), "The narrative construction of reality", Critical Inquiry, Vol. 18, pp. 1-21.

Burgoon, J.K., Buller, D.B., Floyd, K., and Grandpre, J. (1996), “Deceptive realities: sender, receiver, and observer perspectives in deceptive conversations", Communication Research, Vol. 23, pp. 724-748.

Burgoon, J.K., Bliar, J.P., Qin, T., Nunamaker, J.F. (2003), "Detecting deception through linguistic analysis", Intelligence and Security Informatics, No. 2665 in Lecturer Notes in Computer Science, pp. 91-101.

Burgoon, J.K. and Nunamaker, J.F. Jr., eds. (2004), “Toward computer-aided support for the detection of deception", Group Decision and Negotiation, Vol. 13, pp. 14.

Burgstahler, D. and Dichev, I. (1997), "Earnings management to avoid earnings decreases and losses", Journal of Accounting and Economics, Vol. 24, pp. 99126.

Campbell, R.S. and Pennebaker, J.W. (2003), “The secret life of pronouns: flexibility in writing style and physical health", Psychological Science, Vol. 14, pp. 60-65.

Carlson, J.R., George, J.F., Burgoon, J.K., Adkins, M. and White, C.H. (2004), "Deception in computer-mediated communication", Group Decisions and Negotiation, Vol. 13, pp. 5-28.

Cassar, G. (2001), "Self-serving behaviour and the voluntary disclosure of capital market performance", Accounting Research Journal, Vol.14 No.2, pp. 126-137.

Cenesizoglu, T. and Timmermann, A.G. (2008), "Is the distribution of stock returns predictable?" Available at SSRN: http://ssrn.com/abstract=1107185.

Clarke, G. and Murray, L.W. (2000), “Investor relations: perceptions of the annual statement", Corporate Communications: An International Journal, Vol. 5 No. 3, pp. 144-151. 
Clatworthy, M. and Jones, M.J. (2001), "The effect of thematic structure on the variability of annual report readability", Accounting, Auditing and Accountability Journal, Vol. 14 No. 3, pp. 311-326.

Clatworthy, M. and Jones, M.J. (2003), "Financial reporting of good news and bad news: evidence from accounting narratives", Accounting and Business Research, Vol. 33 No. 3, pp. 171-185.

Clatworthy, M. and Jones, M.J. (2006), "Differential patterns of textual characteristics and company performance in the chairman's statement", Accounting, Auditing, and Accountability Journal, Vol. 19 No. 4, pp. 493-511.

Courtis, J.K. (1995), "Readability of annual reports: Western versus Asian evidence", Accounting, Auditing and Accountability Journal, Vol. 8 No. 2, pp. 4-17.

Courtis, J.K. (1998), “Annual report readability variability: tests of the obfuscation hypothesis", Accounting, Auditing and Accountability Journal, Vol. 11 No. 4, pp. 459-471.

Courtis, J.K. (2004a), “Corporate report obfuscation: artefact or phenomenon?", British Accounting Review, Vol. 36 No. 3, pp. 291-312.

Courtis, J.K. (2004b), “Colour as visual rhetoric in financial reporting”, Accounting Forum, Vol. 28 No. 3, pp. 265-281.

Covaleski, M.A., Dirsmith, M.W. and Jablonski, S. F. (1985), "Traditional and emergent theories of budgeting: An empirical analysis," Journal of Accounting and Public Policy, Vol. 4 No. 4, pp. 277-300.

Covey, J.G., Green, K.M. and Slevin, D.P. (2006), "Strategic process effects on the entrepreneurial orientation-sales growth rate relationship", Entrepreneurship Theory \& Practice, Vol. 30 No 1, pp. 57-81.

Crossley, M.L. (2000), "Narrative psychology, trauma and the study of self/identity", Theory Psychology. Vol. 10, pp. 527-546.

Davis, A.K., Piger, J.M. and Sedor, L.M. (2008), "Beyond the numbers: An analysis of optimistic and pessimistic language in earnings press releases", Working paper, April 2008, Available at Social Science Research Network (SSRN), http://ssrn.com/abstract=875399.

Degeorge, F., Patel, J., Zeckhauser, R. (1999), "Earnings management to exceed thresholds", Journal of Business, Vol. 72 No. 1, pp. 1-33. 
DePaulo, B.M., Lindsay, J.J., Malone, B.E., Muhlenbruck, L., Charleton, K. and Cooper, H. (2003), "Cues to deception”, Psychological Bulletin, Vol. 129, pp. 74-112.

Elliott, W.B. (2006), “Are investors influenced by pro forma emphasis and reconciliations in earnings announcements?", The Accounting Review, Vol. 81 No. 1, pp. 113-133.

Frederickson, J.R. and G.S. Miller (2004), "The effects of pro forma earnings disclosures on analysts' and nonprofessional investors' equity valuation judgments”, The Accounting Review, Vol. 79 No. 3, pp. 667-686.

Frink, D.D. and Ferris, G.R. (1998), “Accountability, impression management, and goal setting in the performance evaluation process", Human Relations, Vol. 51 No. 10, pp. 1259-1283.

Gibbins, M., Richardson, A. and Waterhouse, J. (1990), "The management of corporate financial disclosure: opportunism, ritualism, policies and processes", Journal of Accounting Research, Vol. 28 No. 11, pp. 121-143.

Gill, A. and Oberlander, J. (2003), "Perception of email personality at zero acquaintance: extraversion takes care of itself; Neuroticism is a worry", Proceedings of the 25 th Annual Conference of the Cognitive Science Society, Hillsdale, New Jersey, LEA, pp. 363-368.

Godfrey, J., Mather, P. and Ramsay, A. (2003), "Earnings and impression management in financial reports: the case of CEO changes", Abacus, Vol. 39 No. 1, pp. 95-123.

Gupta, S. and Skillicorn, D.B. (2006), "Improving a textual deception detection model", Proceedings of the 2006 conference of the Center for Advanced Studies on Collaborative Research, http://portal.acm.org/citation.cfm?id=1189005.

Hancock, J.T., Curry, L.E., Goorha, S. and Woodworth, M. (2008), "On lying and being lied to: a linguistic analysis of deception in computer-mediated communication, Discourse Processes, Vol. 45 No 1, pp. 1-23.

Hayn, C. (1995), “The information content of losses", Journal of Accounting and Economics, Vol. 20, pp. 125-153.

Healy, P.M. and Wahlen, J.M. (1999). 'A review of the earnings management literature and its implications for standard setting'. Accounting Horizons, 13(4): 365-383.

Heider, F. (1958), The Psychology of Interpersonal Relations, Wiley, New York. 
Henry, E. (2006), "Market reaction to verbal components of earnings press releases: Event study using a predictive algorithm", Journal of Emerging Technologies in Accounting Vol. 3, pp. 1-19.

Henry, E. (2008), "Are investors influenced by how earnings press releases are written?", Journal of Business Communication, Vol. 45 No. 4, pp. 363-407.

Hildebrandt, H.H. and Snyder, R. (1981), "The Pollyanna hypothesis in business writing: initial results, suggestions for research," Journal of Business Communication, Vol. 18 No. 1, pp. 5-15.

Hooghiemstra, R. (2000), “Corporate communication and impression management New perspectives why companies engage in corporate social reporting", Journal of Business Ethics, Vol. 27, pp. 55-68.

Johnson, P., Buehring, A. Cassell, C., and Symon, G. (2006), "Evaluating qualitative management research: towards a contingent criteriology," International Journal of Management Reviews, Vol. 8 No. 3, pp. 131-156.

Jones, M.J. (1988), “A longitudinal study of the readability of the chairman's narratives in the corporate reports of a UK company", Accounting and Business Research, Vol. 18 No. 72, pp. 297-306.

Jones, E.E. and Davis, K.E. (1965), "From acts to dispositions: the attribution process in person perception", In Berkowitz, L. (Ed.) Advances in Experimental Social Psychology, Vol. 2, New York, Academic Press, pp. 219-226.

Kelley, H.H. (1967), “Attribution in social psychology”, Nebraska Symposium on Motivation, Vol. 15, pp. 192-238.

Knee, C.R. and Zuckerman, M. (1996), "Causality orientations, failure and achievement", Journal of Personality, Vol. 62, pp. 321-346.

Kohut, G.F. and Segars, A.H. (1992), “The president's letter to stockholders: and examination of corporate communication strategy", The Journal of Business Communication, Vol. 29 No. 1, pp. 7-21.

Koonce, L. and Mercer, M. (2005), "Using psychology theories in archival financial accounting research", Journal of Accounting Literature, Vol. 24.

Krische, S.D. (2005), “Investors' evaluations of strategic prior-period benchmark disclosures in earnings announcements", The Accounting Review, Vol. 80 No. 1, pp. 243-268. 
Lang, M. and Lundholm, R. (2000), "Voluntary disclosure and equity offerings: Reducing information asymmetry or hyping the stock?", Contemporary Accounting Research, Vol. 17 No. 4, pp. 623-662.

Leary, M.R., Kowalski, R.M. (1990), “Impression management: a literature review and two-component model”, Psychological Bulletin, Vol. 107 No.1, pp. 34-47.

Leary, M.R., Tchividjian, L.R. and Kraxberger, B.E. (1994), "Self-presentation can be hazardous to your health: impression management and health risk", Health Psychology, Vol. 13 No. 6, pp. 461-470.

Letza, S., Kirkbride, J., Sun, X. and Smallman, C. (2008), "Corporate governance theorising: limits critics, and alternatives", International Journal of Law and Management, Vol. 50 No.1, pp. 17-32.

Li, F. (2008), “Annual report readability, current earnings, and earnings persistence”, Journal of Accounting and Economics, Vol. 45 No. 2-3, pp. 221-247.

Macnamara, J. (2003), "Media content analysis: Is uses, benefits, and best practice methodology", http://www.masscom.com.au/book/papers/media_content.html.

Mather, P., Ramsay, A. and Steen, A. (2000), "The use and representational faithfulness of graphs in IPO prospectuses", Accounting, Auditing and Accountability Journal, Vol. 13 No.1, pp. 65-83.

Matsumoto, D., Pronk, M. and Roelofsen, E. (2006), Do analysts mitigate optimism by management? Working paper, University of Washington.

Merkl-Davies, D.M. and Brennan N.M. (2007), 'Discretionary disclosure strategies in corporate narratives: incremental information or impression management?', Journal of Accounting Literature, Vol. 26, pp. 116-196.

Mouck, T. (1995), "Financial reporting, democracy and environmentalism: a critique of the commodification of information", Critical Perspectives on Accounting, Vol. 6, pp. 535-553.

Newman, M.L., Pennebaker, J.W., Berry, D.S. and Richards, J.M. (2003), “Lying words: predicting deception from linguistic styles", Personality and Social Psychology Bulletin, Vol. 29 No.5, pp. 665-675.

Pennebaker, J.W., Chung, C.K., Ireland, M. Gonzales, A. and Booth, R.J. (2007), The LIWC2007 Application, http://www.liwc.net/liwcdescription.php (accessed 10 February 2010). 
Pennebaker, J.W. and Francis, M.E. (1996), "Cognitive, emotional and language processes in disclosure", Cognition and Emotion, Vol. 10, pp. 621-626.

Pennebaker, J.W. and King, L.A. (1999), Linguistic styles: language use as an individual difference, Journal of Personality and Social Psychology, Vol. 6, pp. 1296-1312.

Pennebaker, J.W., Mehl, M.R. and Niederhoffer, K. (2003), "Psychological aspects of natural language use: our words, our selves", Annual Review of Psychology, Vol. 54, pp. 547-577.

Pennebaker, J.W. and Stone, L.D. (2003), "Words of wisdom: language use over the lifespan”, Journal of Personality and Social Psychology, Vol. 85, pp. 291-301.

Powell, T.C. (1996), "How much does industry matter? An alternative empirical test", Strategic Management Journal, Vol. 17 No. 4, pp. 323-334.

Prakash, P. and Rappaport, A. (1977), "Information inductance and its significance for accounting", Accounting, Organisations and Society, Vol. 2 No. 1, pp. 29-38.

Rogers, J.L., Van Buskirk, A. and Zechman, S.L.C. (2009), "Disclosure tone and shareholder litigation", Chicago Booth School of Business Research Paper No. 09-01, http://ssrn.com/abstract=1331608.

Rutherford, B.A. (2003), “Obfuscation, textual complexity and the role of regulated narrative accounting disclosure in corporate governance", Journal of Management and Governance, Vol. 7, pp. 187-210.

Rutherford, B.A. (2005), "Genre analysis of corporate annual report narratives: A corpus linguistics based approach", Journal of Business Communication, Vol. 42 No. 4, pp. 324-348.

Schlenker, B. (1997) "Personal responsibility: applications of the triangle model", in Cummings L.L. and Staw, B. (eds), Research in Organizational Behavior Vol. 19, pp. 241-301.

Schlenker, B.R., Britt, T.W., Pennington, J., Murphy, R., and Doherty, K. (1994), “The triangle model of responsibility", Psychological Review, Vol. 101, pp. 632652.

Slatcher, R.B., Chung, C.K., Pennebaker, J.W. and Stone, L.D. (2007), "Winning words: individual differences in linguistic style among U.S. presidential and vice presidential candidates", Journal of Research in Personality, Vol. 41 No. 1, pp. 63-75. 
Smith, M. and Taffler, R. (1992a), "Readability and understandability: different measures of the textual complexity of accounting narrative", Accounting, Auditing and Accountability Journal, Vol. 5 No.4, pp. 84-98.

Smith, M. and Taffler, R. (1992b), “The chairman's report and corporate financial performance", Accounting and Finance, Vol. 32, pp. 75-90.

Smith, M. and Taffler, R. (1995), "The incremental effect of narrative accounting information in corporate annual reports", Journal of Business, Finance and Accounting, Vol. 22 No. 8, pp. 1195-1210.

Smith, M. and Taffler, R.J. (2000), “The chairman's report: a content analysis of discretionary narrative disclosures", Accounting, Auditing and Accountability Journal, Vol. 13 No. 5, pp. 624-646.

Stanton, P. and Stanton, J. (2002), "Corporate annual reports: research perspectives used". Accounting, Auditing and Accountability Journal, Vol. 15 No. 4, pp. 478500.

Staw, B.M., McKechnie, P.I. and Puffer, S.M. (1983), "The justification of organisational performance", Administrative Science Quarterly, Vol. 28, pp. $582-600$.

Subramanian, R., Insley, R. and Blackwell, R.D. (1993), "Performance and readability: a comparison of annual reports of profitable and unprofitable corporations", The Journal of Business Communication, Vol. 30 No. 1, pp. 4960.

Sydserff, R. and Weetman, P. (2002), "Development in content analysis: a transitivity index and DICTION scores", Accounting, Auditing and Accountability Journal, Vol. 15 No. 4, pp. 523-545.

Tedeschi, J.T., and Riess, M. (1981), "Identities, the phenomenal self, and laboratory research", in J.T. Tedeschi (ed.), Impression Management Theory and Social Psychological Research, New York, Academic Press, pp. 3-22.

Vrij, A., Edward, K., Roberts, K.P. and Bull, R. (2000), "Detecting deceit via analysis of verbal and nonverbal behaviour", Journal of Nonverbal Behaviour, Vol. 24 No, 4, pp. 239-263.

Weber, M. (1968). Economy and Society. 3 Volumes. Towata, Bedminster Press.

Weick, K. (1995). Sensemaking in Organizations. London, Sage.

Zhou, L., Burgoon, J.K., Nunamaker, J.F. Jr., and Twitchell, D. (2004), “Automated linguistic-based cues for detecting deception in text-based asynchronous 
computer-mediated communication", Group Decision and Negotiation, Vol. 13, pp. 81-106. 
Table 1: Sample selection

\begin{tabular}{|c|c|c|c|c|}
\hline & $\begin{array}{r}\text { Consumer } \\
\text { No. firms }\end{array}$ & $\begin{array}{r}\text { Technology } \\
\text { No. firms }\end{array}$ & $\begin{array}{r}\text { Industrial } \\
\text { No. firms }\end{array}$ & $\begin{array}{r}\text { Total } \\
\text { No. firms }\end{array}$ \\
\hline Total population in sector & 360 & 193 & 331 & 884 \\
\hline Eliminations & & & & \\
\hline $\begin{array}{l}\text { Market capitalisation not available/large } \\
\text { change in market capitalisation }\end{array}$ & (18) & (5) & (8) & (31) \\
\hline Missing values & (5) & (17) & (11) & (33) \\
\hline Non-calendar years & (3) & $(7)$ & $(7)$ & (17) \\
\hline Total final population in sector & $\underline{334}$ & $\overline{164}$ & 305 & $\underline{803}$ \\
\hline Sample selected & $\underline{31}$ & $\underline{31}$ & $\underline{31}$ & $\underline{93}$ \\
\hline
\end{tabular}


Table 2: Linguistic indicators of self-presentational dissimulation in chairmen's statements

\section{Linguistic indicator}

1. Word count

2. References to self

3. References to others

4. Positive emotion words

5. Negative emotion words

6. Markers of cognitive complexity
Examples

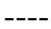

$1^{\text {st }}$ person plural: we, $u s$, our, ours, ourselves; the Group; name of the company

Industry, sector, competitor(s), rival(s)

Exciting, win

Difficult, disappointing, loss

Cognitive processes
Data source

LIWC

Custom dictionary

Custom dictionary

LIWC: Positive emotion

LIWC: Negative emotion

LIWC: Cognitive processes

\section{Measurement}

$\log$ of total word count in text

$\%$ of total word count in text

$\%$ of total word count in text $\%$ of total word count in text $\%$ of total word count in text $\%$ of total word count in text

Note: LIWC: Linguistic Inquiry and Word Count, the content analysis program used in this study 
Table 3: Descriptive statistics of linguistic indicators of self-presentational dissimulation

Variable

1. Word count (absolute total number)

1. Word count (natural log total words)

2. References to self (\%)

3. References to self others $(\%)$

4. Positive emotion words $(\%)$

5. Negative Emotion words (\%)

6. Markers of Cognitive Complexity (\%)

Self-presentational dissimulation $z$ score

Key: $\%=\%$ of total word count in text

$\begin{array}{rrrrrrrr}\mathbf{N} & \text { Mean } & \text { Median } & \text { StDev } & \text { Minimum } & \text { Maximum } & \text { Q1 } & \text { Q3 } \\ 93 & 823 & 806 & 1.876 & 161 & 3,801 & 530 & 1,278 \\ 93 & 6.713 & 6.692 & 0.629 & 5.081 & 8.243 & 6.273 & 7.153 \\ 93 & 3.692 & 3.800 & 1.460 & 0.600 & 7.770 & 2.785 & 4.775 \\ 93 & 0.240 & 0.190 & 0.256 & 0.000 & 1.460 & 0.000 & 0.355 \\ 93 & 3.314 & 3.340 & 1.117 & 1.060 & 7.720 & 2.480 & 3.985 \\ 93 & 0.857 & 0.730 & 0.572 & 0.000 & 3.180 & 0.460 & 1.125 \\ 93 & 3.430 & 3.390 & 0.891 & 0.000 & 5.760 & 2.960 & 3.850 \\ 93 & -0.002 & 1.541 & 2.668 & -6.726 & 7.905 & -1.565 & 1.485\end{array}$

Q3

278

153

775

355

.985

.485 
Table 4: Dependent variable measures and predicted association with organisational outcomes

$\begin{array}{ccc}\begin{array}{c}\text { Self-presentational } \\ \text { dissimulation }\end{array} & \begin{array}{c}\text { Impression management } \\ \text { (enhancement) }\end{array} & \begin{array}{c}\text { Retrospective } \\ \text { sense-making }\end{array} \\ \left(\mathrm{H}_{1} \mathrm{a}, \mathrm{H}_{2} \mathrm{a}, \mathrm{H}_{3} \mathrm{a}\right) & \left(\mathrm{H}_{1} \mathrm{~b}, \mathrm{H}_{2} \mathrm{~b}, \mathrm{H}_{3} \mathrm{~b}\right) & \left(\mathrm{H}_{1} \mathrm{c}, \mathrm{H}_{2} \mathrm{c}, \mathrm{H}_{3} \mathrm{c}\right)\end{array}$

Association with negative organisational outcomes

\section{Linguistic indicator}

1. Word count

2. Self-reference

3. Reference to others

4. Positive emotion words

5. Negative emotion words

6. Cognitive complexity

$\begin{array}{cc}- & \text { Not applicable } \\ - & \text { Not applicable } \\ - & \text { Not applicable } \\ + & \text { No difference } \\ + & + \\ - & \text { Not applicable }\end{array}$

$+$

Not applicable

Not applicable

Not applicable

Not applicable

$+$ 
Table 5: Measurement of organisational outcomes

Proxy measure Definition

(1) Profit / Loss $1 \quad$ EBIT $\geq 0$ in Year 1;

$0 \quad$ EBIT $<0$ in Year 1

(2) Earnings Increase / Decrease

(3) Relative Sales Increase / Decrease

1 Positive change in EBIT Year 0 to Year 1
0 Negative change in EBIT Year 0 to Year 1

1 Positive sales growth relative to industry from Year 0 to Year 1

0 Negative sales growth relative to industry from Year 0 to Year 1

(4) Relative Firm Growth
1 Positive long-term growth averaged over sales and assets and compared to industry, four years from Year -2 to Year +1

0 Negative long-term growth averaged over sales and assets and compared to industry, four years from Year -2 to Year +1
Prior research

Subramanian et al. (1993)

Courtis (2004a)

Li (2008)

Subramanian et al. (1993)

Courtis (2004a)

Powell (1996)

Covey et al. (2006)

\section{Current study} Interest and Tax 
Table 6: Categorisation of sample firms by organisational outcome

$\begin{array}{ccc}\begin{array}{c}\text { Positive organisational } \\ \text { outcome } \\ \text { No. firms }\end{array} & \begin{array}{c}\text { Negative organisational } \\ \text { outcome } \\ \text { No. firms }\end{array} & \text { Total } \\ 52 & 41 & \text { No. firms } \\ 55 & 38 & 93 \\ 57 & 36 & 93 \\ 59 & 34 & 93 \\ & & 93\end{array}$

(1) Profit or Loss

(2) Earnings Increase/Decrease

(3) Relative Sales Increase/Decrease

(4) Relative Firm Growth
59 
Table 7: Descriptive statistics of firm size

$\begin{array}{llrrrrrrr}\text { Variable } & \mathrm{N} & \text { Mean } & \text { Median } & \text { StDev. } & \text { Min } & \text { Max } & \text { Q1 } & \text { Q3 } \\ \text { Size }(£ \mathrm{~m}) & 93 & 45.833 & 43.380 & 8.491 & 0.164 & 6,124.179 & 11.302 & 223.632 \\ \text { LogSize } & 93 & 3.825 & 3.770 & 2.139 & -1.810 & 8.720 & 2.425 & 5.410\end{array}$

Size by industry (£m)

Consumer

Technology

Industrial

$\begin{array}{lll}31 & 85.541 & 58.557 \\ 31 & 16.827 & 22.874 \\ 31 & 66.954 & 94.632\end{array}$

8.593

1259

6124.179

$13.874 \quad 601.845$

$31 \quad 66.954 \quad 94.632$

6.639

$0.164 \quad 749.945$

$5.641 \quad 47.942$

7.838

$1.221 \quad 3261.688$ 
Table 8: Association between self-presentational dissimulation, impression management, and retrospective sensemaking and organisational outcomes $\left(\mathrm{H}_{1}\right)$, firm size $\left(\mathrm{H}_{2}\right)$ and industry sector $\left(\mathrm{H}_{3}\right)$

\begin{tabular}{|c|c|c|c|c|c|c|c|}
\hline $\begin{array}{l}\text { Dependent } \\
\text { variables }\end{array}$ & $\begin{array}{l}\text { (a) Self- } \\
\text { presentational } \\
\text { dissimulation }\end{array}$ & \multicolumn{4}{|c|}{ (b) Impression management (enhancement) } & \multicolumn{2}{|c|}{$\begin{array}{l}\text { (c) Retrospective } \\
\text { sense-making }\end{array}$} \\
\hline $\begin{array}{l}\text { Dependent variable } \\
\text { measures } \\
\text { Hypotheses tested }\end{array}$ & $\begin{array}{r}z \text {-score } \\
\left(\mathrm{H}_{1} \mathrm{a}, \mathrm{H}_{2} \mathrm{a}, \mathrm{H}_{3} \mathrm{a}\right)\end{array}$ & $\begin{array}{r}\text { Self- } \\
\text { reference }\end{array}$ & $\begin{array}{r}\text { Reference } \\
\text { to others } \\
\left(\mathrm{H}_{1} \mathrm{~b}, \mathrm{H}\right.\end{array}$ & $\begin{array}{l}\text { Positive } \\
\text { emotion } \\
\left.\mathrm{H}_{3} \mathrm{~b}\right)\end{array}$ & $\begin{array}{l}\text { Negative } \\
\text { Emotion }\end{array}$ & $\begin{array}{l}\text { Word } \\
\text { count } \\
\left(\mathrm{H}_{1} \mathrm{c}, \mathrm{H}\right.\end{array}$ & $\begin{array}{l}\text { Cognitive } \\
\text { complexity } \\
\left.\mathrm{H}_{3} \mathrm{c}\right)\end{array}$ \\
\hline \multicolumn{8}{|c|}{ Positive / negative organisational outcomes $=$ Profit or loss $(1,0)$} \\
\hline $\begin{array}{l}\text { Organisational } \\
\text { outcomes }\end{array}$ & 1.03 & -0.13 & -1.06 & $* * * 2.69$ & $* * *-2.79$ & 1.48 & $* * *-3.51$ \\
\hline Firm size & $*-1.95$ & $* * * 4.13$ & -0.36 & 1.35 & -1.40 & 0.39 & 1.39 \\
\hline Sector: Constant & $* * 2.04$ & $* * * 5.48$ & $* * * 3.63$ & $* * * 9.24$ & $* * * 7.28$ & $* * * 35.14$ & $* * * 13.43$ \\
\hline Technology (+/-) & -1.04 & 0.24 & -0.01 & $*_{-}-0.73$ & 0.68 & -0.53 & $* * 2.36$ \\
\hline Industrial (+/-) & $* *-2.34$ & $* * 2.23$ & 0.92 & -0.68 & 0.90 & -0.06 & $* * * 3.87$ \\
\hline Adj. $\mathrm{R}^{2}$ & 0.050 & 0.164 & -0.002 & 0.138 & 0.139 & -0.002 & 0.239 \\
\hline \multicolumn{8}{|c|}{ Positive / negative organisational outcomes $=$ Earnings Increase or Decrease $(1,0)$} \\
\hline $\begin{array}{l}\text { Organisational } \\
\text { outcomes }\end{array}$ & 0.11 & 0.97 & -1.58 & $* * * 2.89$ & $* * *-2.99$ & 0.86 & -0.61 \\
\hline Firm size & $*_{-1} 1.67$ & $* * * 4.26$ & -0.59 & $* * 2.16$ & $* *-2.24$ & 0.91 & 0.10 \\
\hline Sector: Constant & $* * 2.13$ & $* * * 5.02$ & $* * * 3.83$ & $* * * 8.65$ & $* * * 7.49$ & $* * * 33.84$ & $* * * 11.78$ \\
\hline Technology (+/-) & -1.12 & 0.27 & 0.03 & $*-1.89$ & 0.83 & -0.63 & $* * 2.47$ \\
\hline Industrial (+/-) & $* *-2.50$ & $* * 2.28$ & 1.10 & -1.09 & 1.34 & -0.27 & $* * * 4.15$ \\
\hline Adj. $\mathrm{R}^{2}$ & 0.039 & 0.173 & 0.014 & 0.148 & 0.149 & -0.0186 & 0.136 \\
\hline \multicolumn{8}{|c|}{ Positive / negative organisational outcomes $=$ Sales Increase or Decrease Relative to Sector Average $(1,0)$} \\
\hline $\begin{array}{l}\text { Organisational } \\
\text { outcomes }\end{array}$ & $* *-1.98$ & 1.30 & 0.65 & 0.68 & $* * *-3.26$ & $* * * 2.92$ & $* *-2.10$ \\
\hline Firm size & -1.33 & $* * * 4.18$ & -0.94 & $* * 2.37$ & $* * *-2.12$ & 0.55 & 0.39 \\
\hline Sector: Constant & $* * * 2.86$ & $* * * 4.84$ & $* * * 3.05$ & $* * * 8.81$ & $* * * 7.65$ & $* * * 34.19$ & $* * * 12.44$ \\
\hline Technology (+/-) & -1.30 & 0.35 & 0.12 & $*_{-} 1.82$ & 0.65 & -0.44 & $* * 2.36$ \\
\hline Industrial (+/-) & $* * *-2.64$ & 2.34 & 1.10 & -1.00 & 1.19 & -0.15 & $* * * 4.15$ \\
\hline Adj. $\mathrm{R}^{2}$ & 0.0793 & 0.180 & -0.010 & 0.072 & 0.163 & 0.064 & 0.1739 \\
\hline \multicolumn{8}{|c|}{ Positive / negative organisational outcomes $=$ Firm Growth $(4$ years) Relative to Sector Average $(1,0)$} \\
\hline $\begin{array}{l}\text { Organisational } \\
\text { outcomes }\end{array}$ & $* * 2.04$ & 1.58 & -0.61 & 0.13 & $* * *-4.55$ & $* * 2.04$ & $* * *-3.13$ \\
\hline Firm size & 0.67 & $* * * 4.13$ & -0.71 & $* * 2.45$ & $* *-1.98$ & 0.67 & 0.60 \\
\hline Sector: Constant & $* * * 33.96$ & $* * * 4.84$ & $* * * 3.49$ & $* * * 9.04$ & $* * * 8.38$ & $* * * 33.96$ & $* * * 13.15$ \\
\hline Technology (+/-) & -0.78 & 0.15 & 0.11 & $*_{-} 1.88$ & 1.23 & -0.78 & $* * * 2.79$ \\
\hline Industrial (+/-) & -0.19 & 2.37 & 1.05 & -1.03 & 1.20 & -0.19 & $* * * 4.23$ \\
\hline Adj. $R^{2}$ & 0.019 & 0.187 & -0.010 & 0.067 & 0.241 & 0.019 & 0.219 \\
\hline
\end{tabular}

Note: This table shows the regression results of (a) self-presentational dissimulation on financial performance (column 1) and (b) the six linguistic indicators of self-presentational dissimulation on financial performance (columns 2-7).

Self-presentational dissimulation $=-\mathrm{z}$ Word Count $-\mathrm{zSelf}$-reference $-\mathrm{z}$ Reference to others $+\mathrm{zPositive} \mathrm{Emotion}+$ zNegative Emotion - zCognitive Complexity.

Z-scores for each indicator are calculated by subtracting the sample mean $\left(\mu_{\mathrm{x}}\right)$ from each value $(\mathrm{x})$ and then dividing by the standard deviation $\left(\sigma_{x}\right)$, i.e. $z_{x}=\left(x-\mu_{x}\right) / \sigma_{x}$.

Positive / negative organisational outcomes is a 0-1 dummy variable, defined as indicated in italics above each set of estimations. Firm size is the natural log of market value. The Consumer Cyclical sector is the reference category for the sector effects.

${ }_{* * *}$ Coefficient or test significant at the $1 \%$ level; ** Significant at the $5 \%$ level; * Significant at the $10 \%$ level. 
